\title{
Fraction of Negligence Costed The Life: (a Fatal Case of Railway Run-Over)
}

\author{
Shahina, Vijayakumar B Jatti and Amit Sharma* \\ Department of forensic medicine and toxicology, India
}

Submission: August 02, 2017; Published: August 16, 2017

*Corresponding author: Dr Amit Sharma, Associate Professor, Department of forensic medicine and toxicology, Hamdard Institute of Medical Science and Research. New Delhi, India, Email: dr_amitsharma@hotmail.com

\begin{abstract}
Incidence of railway injuries are not uncommon, accidental injuries are more common than suicidal, and homicidal being the rare. Pedestrian accidents are more common, the injuries vary from trivial trauma to mutilation/ amputation of the body. Even though the mutilation/amputation is more common in suicidal cases but is also seen in pedestrian accidental cases. The present cases is of an 18 year old girl who met with an accident while she was trying to cross the level bridge were she fall on the track and the train passes over her thighs serving her body in three parts.
\end{abstract}

Keywords: Railways injuries; Accidental amputation

\section{Introduction}

India is a country having $2^{\text {nd }}$ largest network of railway lines in the world and rail is the most used public transportation system. First rail way in India started in 1853 between Bombay and thane, since then Indian railway has spread its branches in all directions to connect all parts of country. Indian railway passes through cities, towns and villages. Many dwelling/ settlements are located close to the tracks and are usually unmanned without any barricades/ signals. The trains of our country are usually overcrowded with people and hence are prone to meet fatalities. Fatal railway injuries may be sustained while crossing the track, jumping in front of train, lying on tack, fall from moving train, collide of trains or derailing of the train. The grievance of injury will depend on the manner of injury. Accidental deaths are more common and in accidental deaths pedestrian accidents are more common [1]. The injury in pedestrian accidents varies from trivial trauma to amputation/ mutilation of the body. Here we are presenting a fatal case of railway run- over of an 18 year old girl while she was trying to cross unmanned level bridge in hurry.

\section{Case Report}

An 18 year old female was brought to hospital in 3 parts (SSIMS, Davangere) with alleged history of accidental railway run over, where she died within an hour of arrival and was shifted to mortuary.

\section{Case History}

As per information furnished by police and relatives, the deceased slipped on the track while she was trying to cross the unmanned level bridge in hurry, neglecting the coming train on the track at Chikkajajur. Before she could have got up from the track, the train passed over her thighs, serving her body in parts.

\section{Autopsy Findings}

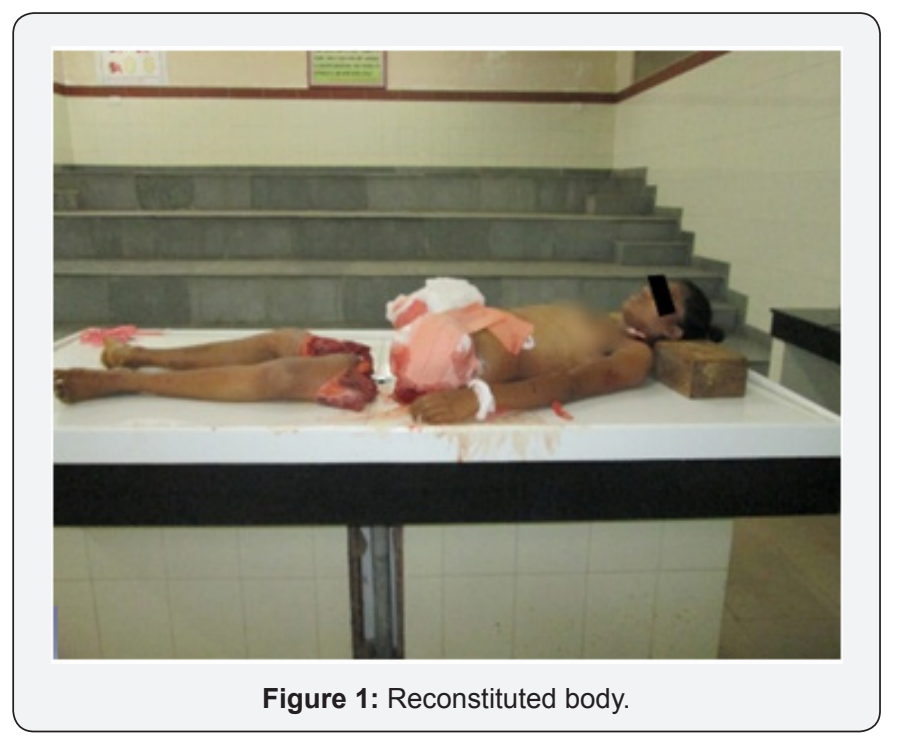


Female aged about 18years, Reconstituted body length measuring $80+65 \mathrm{~cm}(145 \mathrm{~cm})$, moderately built and nourished. Wheatish in skin complexion. Black scalp hair measuring $35 \mathrm{~cm}$. Post-mortem staining was faintly seen at back and was not fixed. Rigor mortis had developed over the head and neck. Blood stains were present over the arms, abdomen \& back of the body. Lips, ear lobules and nail beds appeared pale. Oil and grease stains seen over the chest, abdomen and amputated lower limbs. Blood soaked hospital bandage was present over amputated end of the thighs (Figure 1).

\section{External injuries}

Crush injury with amputation of both the lower limbs present at the level of upper thirds of both thighs, situated $16 \mathrm{~cm}$ below the anterior superior iliac spine. The crushed and lacerated muscles, vessels, nerves, adipose tissue and bones are exposed through amputated cut ends and oozing of blood is seen. Both the amputated lower limbs were completely separated from the trunk. Margins of the crush injury showed oil and grease stains. Laceration measuring $2 \mathrm{~cm} \times 1 \mathrm{~cm} \times$ bone deep present over the dorsal aspect of left $3^{\text {rd }}$ toe (Figure 2).

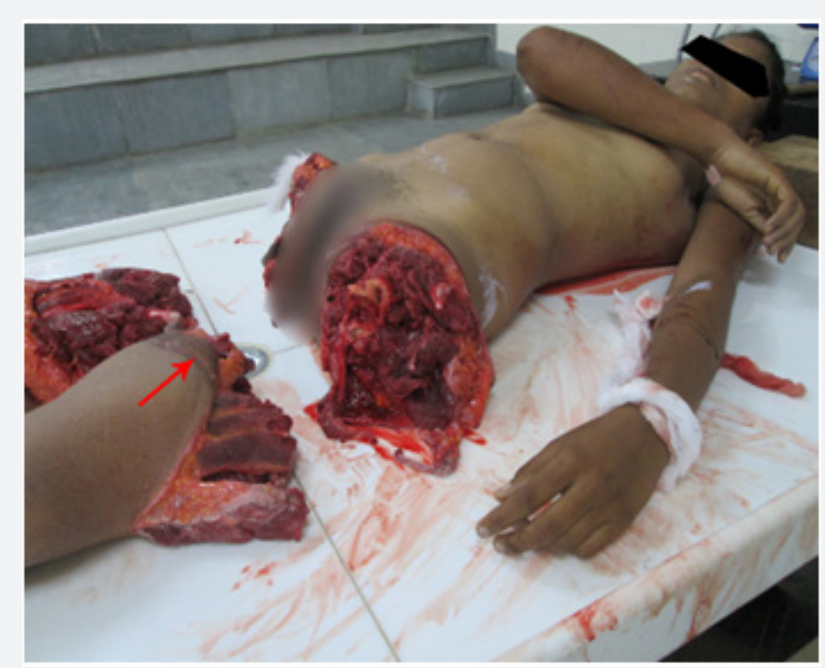

Figure 2: Crush injury with amputation of both the lower limbs.

A. Internal Examination Findings:

a) All internal organs were intact and pale.

B. The external injuries mentioned were of ante-mortem and fresh in nature.

\section{Cause of Death}

"Death is due to Hemorrhagic Shock consequent upon crush injuries of both the thighs as a result of railway run over."

\section{Discussion}

Trains are one of the most important modes of transportation in our country \& have become part of the day to day life of the people. Deaths have occurred in association with railways since the inception of the railway industry. A study conducted by Basavaraj et al. [2] depicted that the males are the commonest victims of railway related deaths. Most vulnerable age group is 21-30 years. Railway deaths are caused by a number of reasons such as; A person under the influence of alcohol loose selfcontrol \& capacity to judge, Many suffer injuries while boarding in and out of the train, While crossing the level bridges etc. While some are caught accidentally, many of the victims with a strong intent to end their life lye own on the track committing suicide.

A retrospective study conducted by Ramesh et al. [3] depicted that accidental deaths are more common $68.8 \%$ and there is male predominance of $92.78 \%$. A study conducted by Mohanty et al. [4] on 88 railway related deaths showed that males are more prone for such injuries, accidental deaths are more common $(80.7 \%)$, with $64.8 \%$ of victims been pedestrians. Decapitation or amputation was common in suicidal cases. Decapitation and mutilation of body is most commonly see in suicidal cases $[1,5,6]$. In present case it was mere negligence on part of deceased and inappropriate safety measures on part of the government / railway department that made this 18 year old girl to lose her life.

\section{Conclusion}

There are various cases of railway injuries the pattern of wounds depends on the position of the victim at the time of incident. Mutilations of body, decapitation or amputation are more commonly see in suicidal cases. But in this cases accidental fall on rail track has let to railway run-over and the body of victim was served in pieces. The injuries sustained on railway track are usually most fatal \& can occur accidentally due to mere lack of attention, usage of phones, urgency to catch train etc.

These injuries can better be prevented rather than treated.

\section{Prevention}

The accidental railway deaths in future can be reduced by

a) Implementing safety measures,

b) Reducing the public access to railway tracks by strict vigilance,

c) Educating the public about dangers of railway trespassing.

d) Displaying signal boards,

e) Construction of overhead pathways and manned crossing levels.

\section{References}

1. Nandy A (2014) principles of forensic medicine including toxicology. ( $3^{\text {rd }}$ edn). New central book agency pvt ltd, Kolkata, India, pp. 473-475.

2. Patil B, Raghavendra KM, Syed U, Deepak (2011) A study on pattern of injuries in railway deaths. Indian $\mathrm{j}$ of forensic medicine toxicology 5(1): 20-22. 
3. Savaradekar R, Dere R, Buchade D, kukde H, et al. (2013) a two years retrospective study of pattern of railway fatalities cases brought to sion hospital mumbai. Medico-legal update 13(1): 95-98.

4. Mohantymk, panigrahimk, Mohanty s, Patnaikkk (2007) Death due to traumatic railway injury. Med sci law 47(2): 156-160.
5. Modi (2011) Textbook of medical jurisprudence \&toxicology $\left(24^{\text {th }}\right.$ edn). Nagpur 581-82.

6. Reddy Ksn, Opm P Murthy (2015) The essentials of forensic medicine \& toxicology (31 ${ }^{\text {st }}$ edn). Jaypee B pp. 1- 267.

\section{Your next submission with Juniper Publishers} will reach you the below assets

- Quality Editorial service

- Swift Peer Review

- Reprints availability

- E-prints Service

- Manuscript Podcast for convenient understanding

- Global attainment for your research

- Manuscript accessibility in different formats ( Pdf, E-pub, Full Text, Audio)

- Unceasing customer service

Track the below URL for one-step submission https://juniperpublishers.com/online-submission. 